\title{
Sequence stratigraphic approach to hydrocarbon exploration: a case study of Chiadu field at eastern onshore Niger Delta Basin, Nigeria
}

\author{
Victor C. Nwaezeapu ${ }^{1}$ Anthony U. Okoro ${ }^{1}$ Elesius O. Akpunonu ${ }^{1}$ • \\ Norbert E. Ajaegwu ${ }^{1} \cdot$ Kingsley C. Ezenwaka ${ }^{1}$ Chibuzo V. Ahaneku ${ }^{1}$
}

Received: 18 April 2017/ Accepted: 20 November 2017/Published online: 28 November 2017

(c) The Author(s) 2017. This article is an open access publication

\begin{abstract}
This study integrated lithofacies, foraminifera and seismic data to develop a sequence stratigraphic approach to hydrocarbon exploration for Chiadu field. The application of lithostratigraphic approach led to correlation of diachronous lithofacies and wrongly defined an approximately accurate extent of the reservoirs. This study necessitated the use of sequence stratigraphic framework for the purpose of establishing chronostratigraphic concept and facies prediction. The genetic sequence model of Galloway was adopted for sequence stratigraphic interpretation of the field. The structural style is dominated by closely spaced simple rollover anticline bounded by growth faults, and this includes down-to-basin listric faults, collapsed crest structures, antithetic and synthetic faults. Result of foraminifera analysis showed that the analyzed interval is very rich in calcareous benthic but decreased in planktic and arenaceous benthic foraminifera. Lithofacies analysis shows that the continental lithofacies is made up of dominantly sand with thin bands of shales, while Agbada lithofacies is made up of alternating intervals of sandstones and shales to very thick shale unit in the lower section. The facies identified using log motifs and their stacking patterns include braided fluvial, crevasse splay, fluvial point bar, distributary/tidal channels, intertidal, subtidal and storm-dominated shelf facies. The presence of water depth indicator fossils confirmed the water depths of coastal deltaic, shallow inner neritic, inner neritic, middle neritic and outer neritic were based largely on the presence of environmentally restricted benthic foraminifera species.
\end{abstract}

Victor C. Nwaezeapu

victor.nwaezeapu@gmail.com

1 Department of Geological Sciences, Nnamdi Azikiwe University, Awka, Anambra State, Nigeria
Integration of lithofacies and biofacies data suggests depositional environments ranging from coastal deltaic to outer neritic environment. Sequence stratigraphic analysis identified three complete sequences with accompanying system tracts over the interval $7922.3-14,856.34 \mathrm{ft}$. The transgressive system tracts (TSTs) within these sequences are dominated by marine shales and thin sands. Reservoir quality sands are found in highstand system tract and shelfal lowstand system tract, while the shales of TSTs and HSTs form potential source and seal units. The delineation and correlation of sequence stratigraphic surfaces enable us to build an approximate chronostratigraphic framework, which is essential for determining facies relationships. Reacquisition and/or processing should be done to improve seismic data quality for better imaging and interpretation/ mapping, especially hydrocarbon prospect at deeper horizon.

Keywords Sequence stratigraphy - Genetic sequence . Foraminifera $\cdot$ Lithofacies $\cdot$ Depositional environment

\section{Introduction}

Hydrocarbon accumulations are becoming increasingly difficult to find as nearly all the simple entrapments have been discovered. Integrated interpretation of all relevant subsurface information in a sequence stratigraphic approach has become a critical requirement for new discoveries. Sequence stratigraphy examines the spatial and temporal rock relationship within a chronostratigraphic framework of repetitive, genetically related strata bounded by surfaces of erosion or non-deposition, or their correlative conformities (Posamentier and Vail 1988). In more realistic terms, sequence stratigraphy establishes the 
analysis of cyclic sedimentation patterns that are present in stratigraphic successions as they develop in response to various variations in sediment supply and accommodation (Posamentier and Allen 1999). Subsequently, Wheeler (1958, 1959), Weller (1960) and Sloss (1962, 1963) recognized the importance and utility of correlating timesynchronous surfaces across geological sections and further refined these concepts. Predicting the lateral and vertical distribution of depositional sequences and their component system tracts and facies plays a significant role in exploration for and development of clastic reservoirs (Slatt 2006).

The Niger Delta sedimentary basin situated in the Gulf of Guinea is comprised of traditionally three stratigraphic units of variable geologic characteristics. These can be grouped as topset beds, foresets and bottomset as revealed from seismic stratigraphy (Galloway 1975). The topset portion known as regressive continental unit called the Benin Formation; the foreset unit forms the prograding Agbada Formation, whereas the marine clay/ shale of the Akata Formation is referred as the bottomset portion of the delta depositional system. Several works carried out by researchers revealed the stratigraphy, sedimentology, structural styles and the play potential of the basin (Adesida and Reijers 1977; Avbovbo 1978; Reijers 2011).

Stratigraphically, the delta-top Benin Group (Reijers 2011) overlies the delta-front Agbada Group and the prodelta Akata Group. The make-up of the subsurface Benin Group reflects the present-day Quaternary land and swamp outcrops; the Agbada Group reflects the beach ridges and the Akata Group the offshore sands, silts and clays.

Formal biostratigraphical, sedimentological and sequence stratigraphic studies (Ladipo 1992; Stacher 1995; Reijers et al. 1997) unveiled the compounded influence of eustatic cyclicity and local tectonics. Depositional sequences made up of strata bounded by unconformities and their lateral equivalents are only observed in specific sectors of the delta, and in contrast, delta-wide genetic sequences as defined by Galloway (1989) are more readily identifiable in the Niger Delta (Reijers 2011).

Sequence stratigraphic technique applied in several sedimentary basins in the world has led to the discovery and recovery of more hydrocarbon reserves. In the north Central Gulf of Mexico, this method improved reservoir development and management strategies, provided information into basin fill history, and aid to the ongoing exploration successes in the basins (Meckel 2003). In the outer continental shelf Gulf of Mexico, $61 \%$ of proved reserves, $40 \%$ of produced hydrocarbon and $40 \%$ of remaining reserves were identified using high-frequency sequence stratigraphic technique (Rassi 2002; Rassi and Hentz 2003; Hentz et al. 2002).
Over the years, the concept of lithostratigraphic has been used to delineate reservoir tops in search for hydrocarbon in the oil and gas industries. In this field of study, the lithostratigraphic approached led to correlation of diachronous lithofacies, which wrongly defines an approximately accurate extent of the reservoirs, and consequently resulted to unforeseen financial investment problem. The quest for a better and more reliable approach for exploration and correlation of oil and gas reservoirs has necessitated using sequence stratigraphic concept in Chiadu field. The aim of this study involves the application of sequence stratigraphic technique in the prediction of depositional facies to identify potential source sediments, reservoirs and sealing potentials, and to identify exploration and production potentials within the field.

The application of sequence stratigraphic concept in studying the various hydrocarbon fields in the Niger Delta sedimentary basin is relevant to improved exploration techniques and the discovery of unidentified resources. The technique serves as an analogue for both local and regional mapping and correlation of stratal units. The division of depositional packages into genetic units is well understood through the concept of sequence stratigraphy.

Emery and Myers (1996) provided a detailed review of sequence stratigraphic framework and their application in various depositional environments.

Sequence stratigraphy has become key significant helpful techniques in generating exploration prospects and predicting reservoir and seal quality in both stratigraphic and structural prospects. This concept encompasses the integration of seismic data, well logs and high-resolution biostratigraphic data, resulting in chronostratigraphic framework for the interpretation, correlation and mapping of sedimentary packages. It involves the spotting of the key bounding surfaces, system tracts and genetic sequences. Sequence stratigraphic approach enables the formation of the most realistic, plausible and predictive model.

\section{Location and geology of the study area}

The field under investigation is located in the Coastal Swamp Depobelt of Niger Delta Basin (Fig. 1). The field is located between longitudes $6^{\circ} 57^{\prime} 4.997 \mathrm{E}$ and $7^{\circ} 06^{\prime} 11.436 \mathrm{E}$ and latitudes $4^{\circ} 28^{\prime} 21.684 \mathrm{~N}$ and $4^{\circ} 34^{\prime} 8.697 \mathrm{~N}$. It is bounded in the east, west and south by the Calabar Flank, Benin Flank and the Gulf of Guinea, respectively. Niger Delta is bounded in the north by older (Cretaceous) tectonic elements among which are the Anambra Basin, Abakaliki uplift and Afikpo syncline. Weber and Daukoru (1975) suggested that the basin that facilitated and controlled the formation of the present Niger Delta was developed by rift faulting during the Precambrian. Benin and Calabar Hinge lines are the 


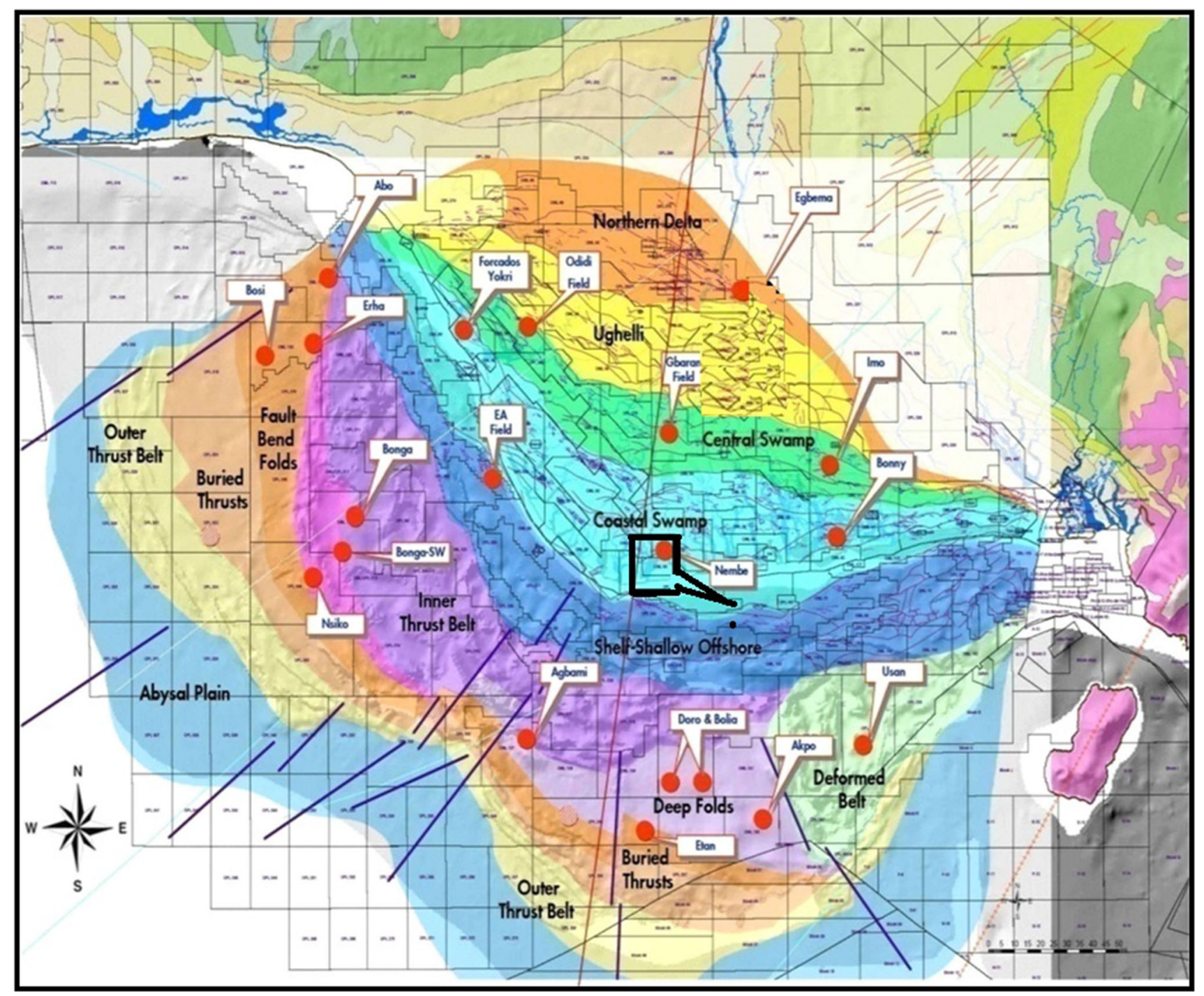

Fig. 1 Location map of Niger Delta showing the study area

deep-seated faults associated with the rifting controlled formation of the delta. The building of the Niger Delta over the edge of the African continent began in the middle-late Eocene (Hospers 1965). Evidence from the geophysical investigations indicates that the oligocene and younger sediments are progressively toward the continental shelf and that they average $26,000 \mathrm{ft}(7924 \mathrm{~m})$. The accumulation of these sediments was rather fast, and hence, gravitational movements within them became pronounced, resulting in contemporaneous faulting with deposition (growth faults).

\section{Regional tectonic setting}

The Niger Delta Basin is located within the perioceanic section of the Abakaliki-Benue suture zone of the much larger southern Nigerian basin. On the west, it is separated from the Dahomey (or Benin) basin by the Okitipupa basement high, and on the east it is bounded by the Cameroun volcanic line. Its northern margin transects several older (Cretaceous) tectonic elements the Anambra basin, Abakaliki uplift, Afikpo syncline and Calabar Flank. The evolution of the delta is controlled by pre- and synsedimentary tectonics as described by Evamy et al. (1978), Ejedawe (1981), Knox and Omatsola (1989) and Stacher (1995). The tectonic framework of the continental margin along the West Coast of equatorial Africa is controlled by Cretaceous fracture zones expressed as trenches and ridges in the deep Atlantic. The trough represents a failed arm of a rift triple junction associated with the opening of the South Atlantic. In this region, rifting started in the Late Jurassic and persisted into the Middle Cretaceous (Lehner and De Ruiter 1977). In the region of the 
Niger Delta, rifting diminished altogether in the Late Cretaceous.

\section{Materials and methods}

\section{Materials}

The study uses a volume of 3D seismic reflection data that covers $485-\mathrm{km}^{2}$, well-log, checkshot and high-resolution biostratigraphic data.

\section{Well-log interpretation}

The well-log data used for this interpretation comprise gamma-ray logs with counts measured on the horizontal scale from 0 to 150 calibrated in standard American Petroleum Institute (API). A shale baseline of 64 API was chosen to discriminate between sands and shales. The sand bodies were identified by the gamma-ray log (GR) deflection to the left due to low concentration of radioactive minerals. Shales have high concentration of radioactive minerals and are delineated by GR deflection to the right. Accumulation of sediments that reflect different depositional environments tends to display characteristic $\log$ motifs, and the recognition of these log motif trends has herein been used as an indicator of the likely depositional settings of the facies succession.

Sand percentages were derived from the gamma-ray log motifs by subtracting one from the volume of shale, which is given as $V_{\mathrm{sh}}=\mathrm{GR}_{\log }-\mathrm{GR}_{\min } / \mathrm{GR}_{\max }-\mathrm{GR}_{\min }$, where $V_{\text {sh }}$ is the volume of shale, $\mathrm{GR}_{\log }$ is the gamma-ray reading of the formation, $\mathrm{GR}_{\min }$ is the minimum gamma-ray reading (sand baseline) and $\mathrm{GR}_{\max }$ is the maximum gamma-ray reading (shale baseline). The calculated sand percentages from the log motifs together with lithofacies description of the log motifs were integrated to describe the paleoenvironment of the deposition.

The methods for environment diagnostic approach by Cant (1984, 1992), Anderson et al. (1982), Serra and Abbott (1982) and Rider (1990) were adopted for the study. The well logs were also interpreted to delineate the stratigraphic tops that represent time stratigraphic surfaces within the study area. The base of the Agbada Formation and the top of the Akata Formation could not be interpreted from well data due to the shallow depth penetrated by the well.

\section{3-D seismic interpretation}

The original use of seismic reflection data was to create quality geological maps depicting the geometry of a subsurface structure. With the advances in seismic technology, structural mapping is the foremost fundamental step in subsurface interpretation. The 3-D seismic structural interpretation of Chiadu field is based primarily on the seismic reflectors and their terminations against fault. The survey has SEG normal polarity, meaning that increasing amplitude (positive amplitudes) is represented by peak with blue color, while decreasing amplitude (negative amplitudes) is represented by trough with red color. In the survey, the area of interest is located between $1200 \mathrm{~ms}$ and $2900 \mathrm{~ms}$.

Major and minor faults were identified based mainly on break in reflection events or abrupt termination of reflection events. The faults are represented on the seismic section as discontinuous lines along a preferred orientation of reflectors. The faults were picked by assigning names, and these were transferred from dip section to the strike sections of the seismic section.

The corresponding seismic reflection events that show reasonable amplitude and continuity were selected. Three horizons ( $\mathrm{H} 1, \mathrm{H} 2$ and $\mathrm{H} 3)$, which represent the sequence stratigraphic surfaces: maximum flooding surfaces (MFS1, MFS2 and MFS3), were identified. Two of the horizons (H2 and H3) selected were mapped through all the seismic sections. The location of horizon (H1) shows a chaotic reflection and was not correlated and may require further seismic processing to define it.

\section{Biostratigraphic interpretation}

This provides information on depositional environments and paleobathymetry of the study area. The paleobathymetry of sediments in the various system tracts was determined using the benthic foraminiferal assemblages (Vail and Wornardt 1991; Mitchum et al. 1993). The biostratigraphic data provided were used to recognize the changes in relative paleobathymetry, leading in turn to the recognition of key stratigraphic surfaces, parasequences and system tracts.

The idea of using fossil abundance for correlation dates back to Israelsky (1949). He stated that "the recognizable timeline that formed by connecting the deepest points of deposition in various columns (wells) and that the floods of individuals and species were found at these points in the well samples". The key bounding surfaces identified in the studied wells are the maximum flooding surfaces (MFSs) and the sequence boundaries (SBs). The biostratigraphic interpretation was focused on the identification of major faunal abundance and diversity peaks, which coincided with MFS within condensed sections, while faunal abundance and diversity minima corresponded to SB.

Biostratigraphic chart from Chiadu Field well A (Fig. 2) was used to correlate with other wells in the field. The 


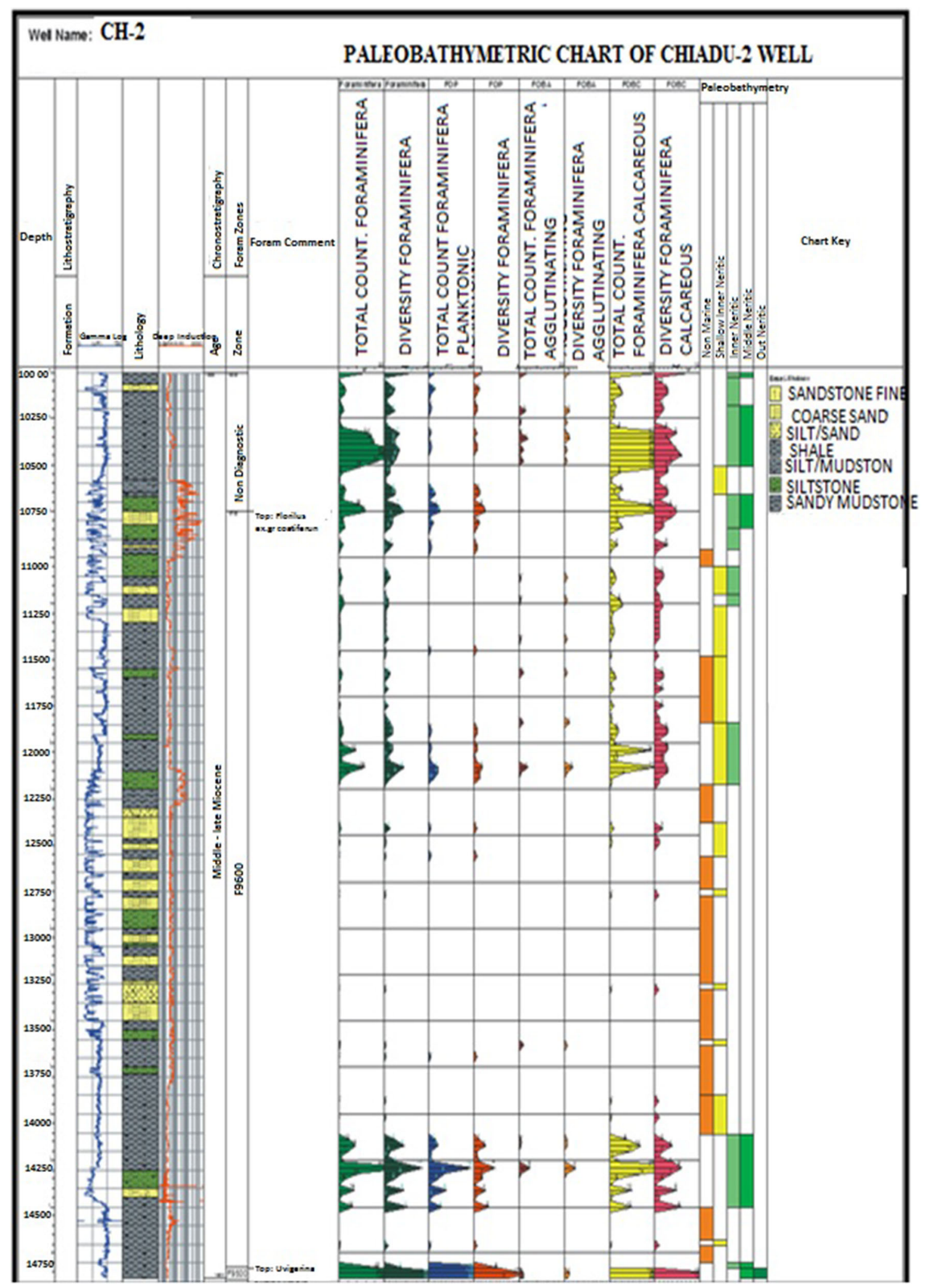

Fig. 2 Biostratigraphic chart of well A 
foraminifera interpretations were based on planktic and benthic foraminifera diversity and abundance.

\section{Fossil assemblages}

Fossil assemblages used to interpret the various water depths (paleobathymetry) of the sediments penetrated by the studied well include the following:

Coastal deposit: Textularia sp., Quinqueloculina sp., Globigerinoides sp.

Shallow inner neritic: Globigerina sp., Uvigerina sp., Bolivina sp., Alabamina sp.

Inner neritic: Cibicides sp., Eponides sp., Triloculina sp., Nonion sp.

Inner neritic to middle neritic: Triloculina sp., Nonionella sp., Globigerina sp., Alabamina sp., Textularia sp.

Middle neritic: Verneuilina sp., Trochammina sp., Anomalina sp., Trochamminoides sp.
Outer neritic: Globigerinoides $\underline{\text { sp. }}$

\section{Results and discussion}

\section{Lithofacies delineation}

A detailed lithofacies description using gamma-ray log motifs was carried out on well A, well B and well C. The wells were drilled in a north-south direction: well $\mathrm{C}$, well $\mathrm{B}$ and well A (dip direction). The gamma-ray log signatures of well C, well B and well A penetrated the continental (Benin Formation) and some portion of the paralic Agbada Formation (Fig. 3). Each of these lithofacies units was discussed on the basis of thickness of sand/shale. The entire stratigraphic package mapped in the study area was generally grouped into two main lithofacies, namely Benin lithofacies and paralic Agbada lithofacies.

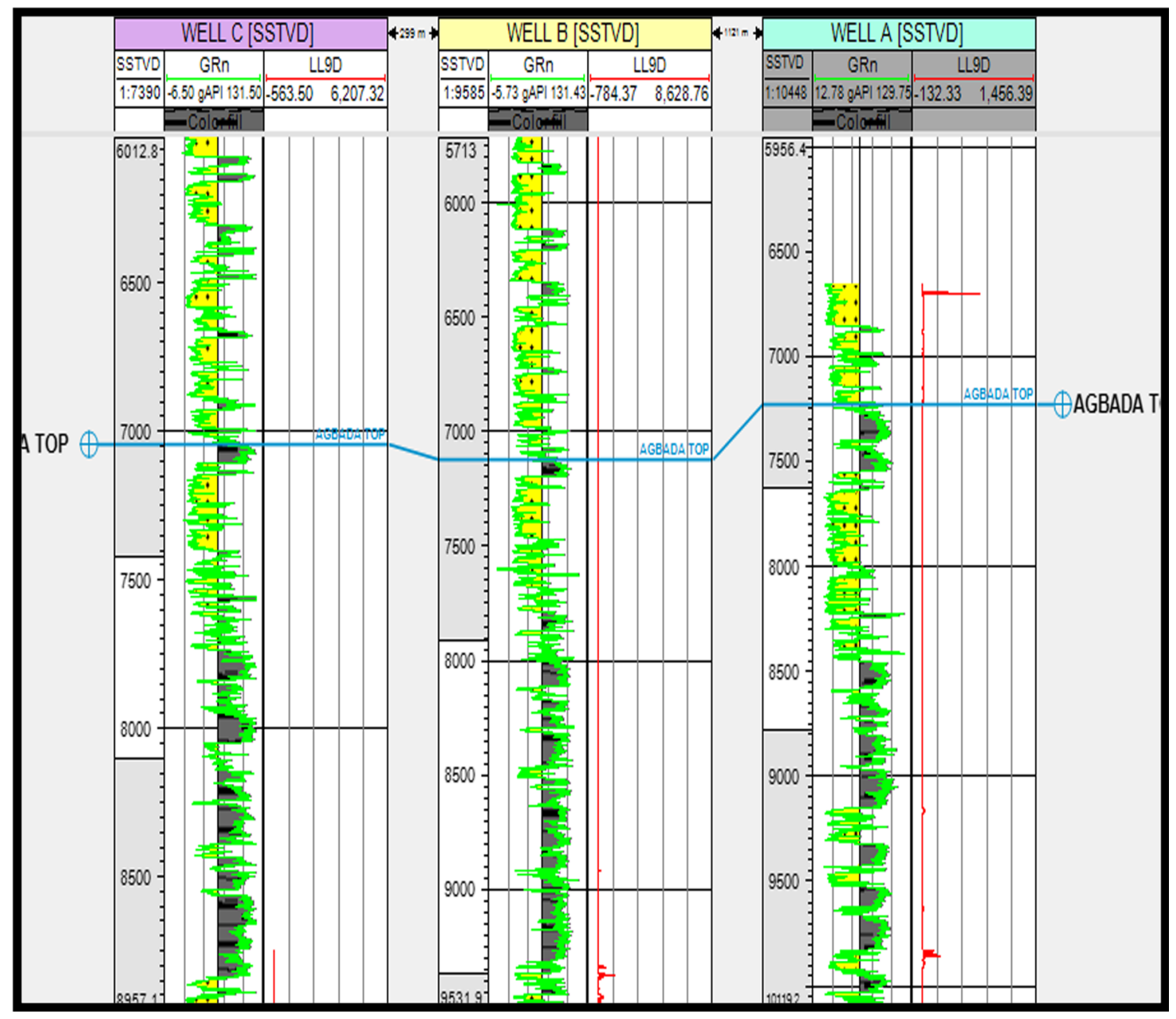

Fig. 3 Identification of Agbada top penetrated by well A, well B and well C 


\section{Benin lithofacies}

Selley (1978) stated that the shapes of well-log curve have long been interpreted in terms of depositional facies because of their resemblance to grain size succession. Three (3) distinctive log motifs were identified and correlated across other wells in the field of study.

\section{Interval 5044.22-4409.2 ft}

This subunit is about $635 \mathrm{ft}$ thick and consists of very thick sand. It has a sand percentage of about $86 \%$. On gammaray $\log (\mathrm{GR})$ motif of well $\mathrm{C}$, this interval is characterized by dominant blocky units or cylindrical shape, indicates massive or thickly bedded sand with very thin shale intercalation and is suggestive of fluvial braided stream subfacies environment. Cant (1992) classified cylindricalshaped gamma-ray log motif with no trend as braided fluvial. The interval was correlated with well $\mathrm{B}$ at
4531.59-4040.71 ft. This section was missing in well A and was not correlated (Fig. 4).

Intervals 5576.64-5044.22, 6083.39-5595.88 and 7026.34-6307.90 ft

These subunits are about 532.42, 487.51 and $718.44 \mathrm{ft}$ thick across the three wells with an average sand percentage of about $79 \%$. These subunits consist of thick sands that are separated by thin bands of shale. On gamma-ray $\log$ motif of well $\mathrm{C}$, this interval is characterized by fining upward unit (bell-shaped log motif) and is suggestive of fluvial point bar (meandering river) subfacies environment. Rider (1990) classified bell shape with abrupt base as fining upward fluvial point bar. The shale is interpreted as flood plain/over bank deposits. The intervals were correlated with well $B$ at 5113.99-4564.87, 5828.51-5138.95 and $7118.11-6420.23 \mathrm{ft}$ and well $\mathrm{A}$ at $7235.17-6854.26 \mathrm{ft}$ (Fig. 4).

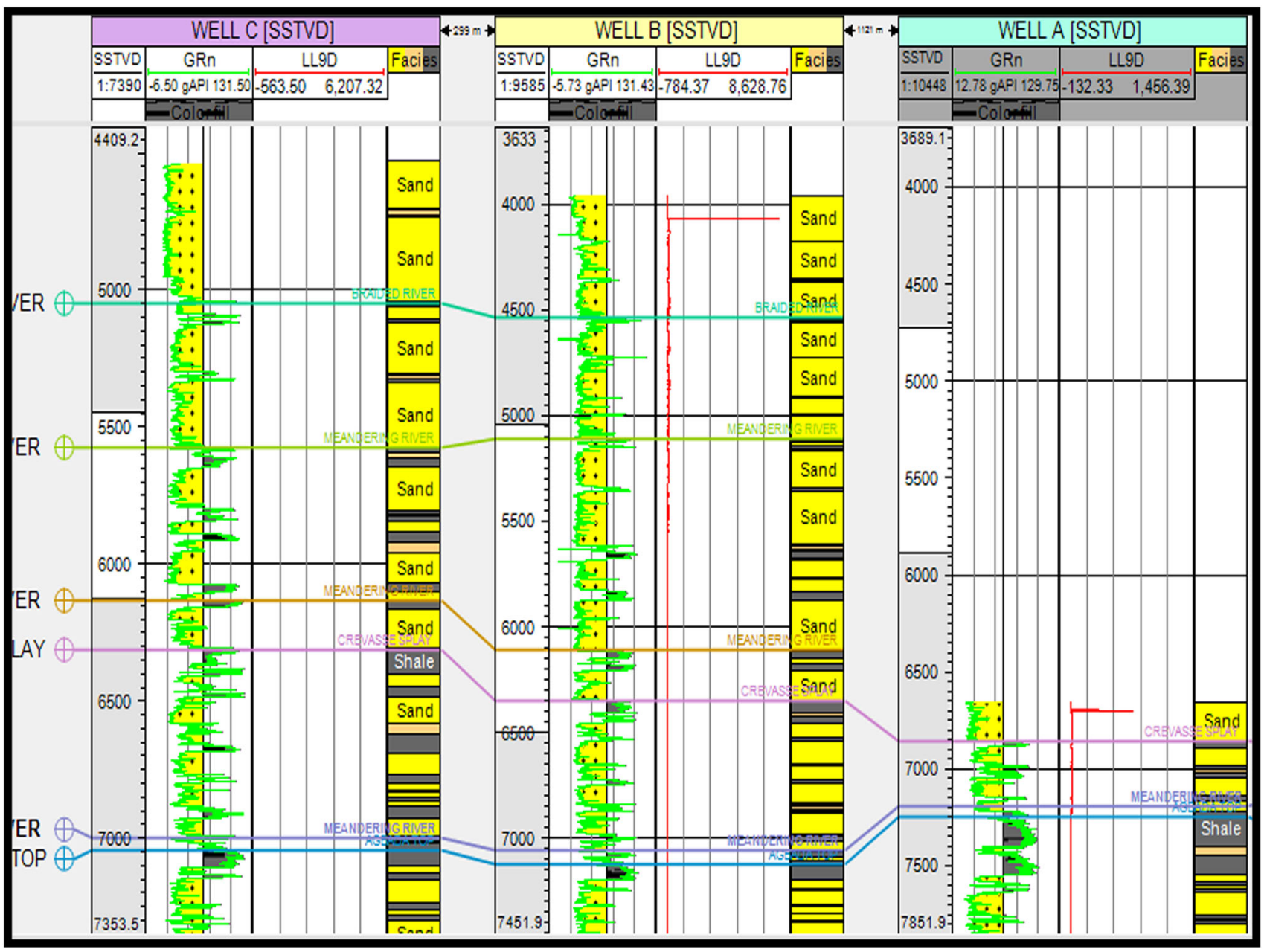

Fig. 4 Subfacies units correlation across the wells within Benin formation 


\section{Intervals 6301.49-6070.56 ft}

This subunit is about $230.93 \mathrm{ft}$ thick and consists of relatively thick sand. On gamma-ray log motif of well $\mathrm{C}$, this interval is characterized by coarsening upward log motif (funnel-shaped log motif) with a very high sand percentage of about $75 \%$ and is suggestive of a crevasse splay subfacies environment. Cant (1992) showed that funnelshaped gamma-ray log motif with abrupt top as coarsening upward crevasse splay. The interval was correlated with well $\mathrm{B}$ at $6337.03-6203.91 \mathrm{ft}$ and well $\mathrm{A}$ at 6854.26-6654.74 ft (Fig. 4).

\section{Paralic Agbada lithofacies}

\section{Interval 7987.91-7235.17 ft}

This subunit is about $754.74 \mathrm{ft}$ thick. This unit consists of relatively thick shale and very thick sand unit. On gamma- ray log motif of well A, the sand shows a slightly serrated blocky-shaped log motif with sand percentage of about $45 \%$ and is interpreted as distributary channel subfacies environment, while the shale represents bayfill and shelf mud deposited in shallow marine coastal settings. The interval was correlated with well C and well B at 7398.39-7071.24 and 7485.19-7118.11 ft (Fig. 5).

\section{Interval 11,980.24-7987.91 ft}

This subunit is about $3992 \mathrm{ft}$ thick. This unit is comprised of heterolithic lithology made up of beds of sandstone and shales. It has a sand percentage of about $24 \%$. This sandstone unit of well A exhibits fining upward serrated gamma-ray log motifs and is interpreted as intertidal subfacies environment. Cant (1992) classified bell-shaped gamma-ray $\log$ motif as fining upward tidal point bar within the shallow marine tidal environment. The interval

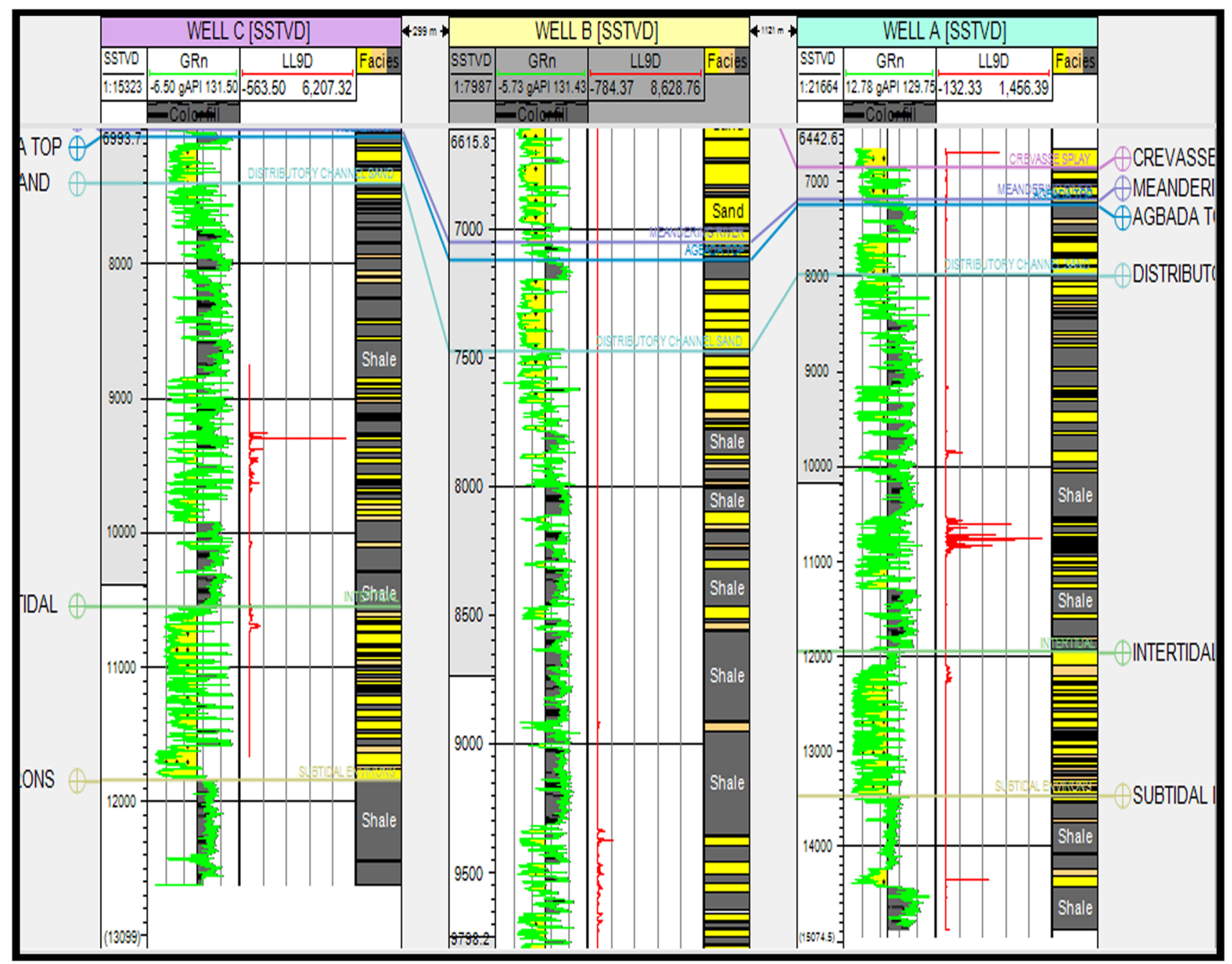

Fig. 5 Correlation of well A, well B and well C 


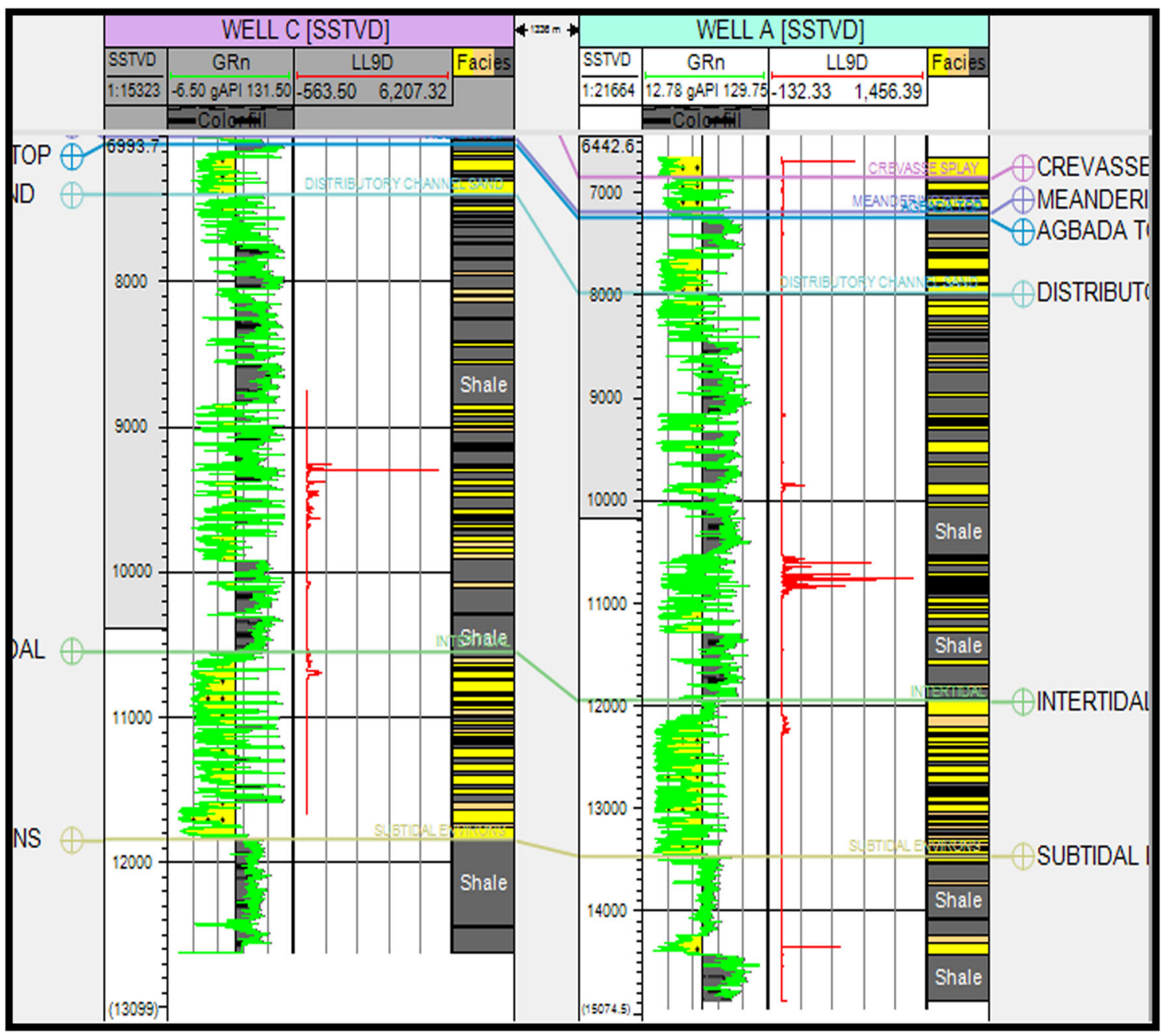

Fig. 6 Correlation of well A and well C

was correlated with well $\mathrm{C}$ and well $\mathrm{B}$ at 10,841.55-7398.39 and 9831.43-7485.19 ft (Fig. 5).

\section{Interval 13,485.74-11,980.24 ft}

This subunit is about $1505.5 \mathrm{ft}$ thick. This unit is comprised of very thick sands separated by very thin bands of shale. It has a sand percentage of about $50 \%$. On gammaray $\log$ motif of well $\mathrm{A}$, the sandstone shows a fining upward $\log$ motif and is suggestive of subtidal subfacies environment. Cant (1992) classified bell-shaped gammaray $\log$ motif as fining upward tidal point bar within the shallow marine tidal environment. The interval was correlated with well $\mathrm{C}$ at $11,856.55-10,547.97 \mathrm{ft}$ (Fig. 6). This section was missing in well B.
Interval 14,889.61-13,485.74 ft

This subunit is about $1403.87 \mathrm{ft}$ thick. This unit is comprised of very thick shale separated by thin interbedded sands. It has a very low sand percentage of about $10 \%$. The sands show serrated and symmetrical gamma-ray log motifs and are suggestive of storm-dominated shelf and rework offshore bar. Cant (1992) classified symmetrical gamma ray log motif as a sandy offshore bar. The interval was correlated with well $\mathrm{C}$ at $12,632.72-11,856.55 \mathrm{ft}$ (Fig. 5). This section was missing in well B.

\section{Biofacies interpretation}

The stratigraphic intervals studied in well A have been characterized or subdivided based on their foraminifera contents (planktics and benthics) (Fig. 2). Species abundance and diversity are more reliable in correlating strata and dating sequences (Huang and Worrandt 1986; 
Armentrout 1987). The planktic foraminifera preservation in well A is poor, but the benthic foraminifera assemblages found in the same well are well preserved in contrast to the planktic foraminifera. Results of foraminifera analysis showed that well A is very rich in calcareous benthic and low in planktic foraminifera but very low in arenaceous benthic foraminifera (Fig. 2).

The inference of the paleobathymetry of intervals $10150,10270,12529,12550$ and $13630 \mathrm{ft}$ as coastal deltaic is based on the following criteria:

1. The intervals are completely barren of microfauna or containing very few benthic and planktic foraminifera like Textularia sp., Quinqueloculina sp., Globigerinoides obliquus and globigerina glutinata.

2. The intervals are characterized by fine-mediumgrained through coarse-grained sand or mudstone.

The inference of the water depth of the intervals 10060 , 10510-10690, 10810-10840, 10960, 11080, 11140, 11200, 11290-11440, 11500-11530, 11620, 11710, 11800, 11860-11890, 11980, 12070-12100, 12190-12220, $12460-12610,128220,13330,13960,14020,12610$, $14140,14200-14230,14410-14410-14440$ and $14710 \mathrm{ft}$ as shallow inner neritic is based on the following reasons:

1. The indicator fauna found here are globigerina glutinata Uvigerina subperegrina, Bolivina spathulata and Alabamina sp.

2. The population count of the calcareous benthic forms within these intervals is higher than that of the planktic forms but barren completely of arenaceous benthic foraminifera.

3. The lithology of the intervals is composed of finemedium-grained sand, silt and mudstone.

The inference of the paleodepth of these intervals 10090-10120, 10180, 10240, 10360-10420, 10720-10780, 10960, 11110, 11920-12040, 14170, 14260, and $14320 \mathrm{ft}$ as inner neritic is based on the following recognition:

1. The population count of calcareous benthic foraminifera is higher than that of planktic but barren or contains very few arenaceous benthic foraminifera. The average planktic/benthic is low.

2. The indicator fauna found here are Cibicides boueanus, Eponides umbonatus, Triloculina trigonula and Nonion sp.

3. The lithology is characterized by fine-medium-grained sand, silt and mudstone.

The inference of the water depth of these intervals $10000,10210,10330,10450,10480,10750,11230-11260$, 14290, 14410, 14500 and $14860 \mathrm{ft}$ as inner neritic to middle neritic is based on the following findings:
1. There is an increase in the population of the planktics and increased in species diversity. Also planktic/ benthic ratio is increased. Very few or barren of arenaceous benthic foraminifera is observed but high abundance and diversity of calcareous benthic foraminifera.

2. The occurrence of the typical foraminifera taxa from inner, middle and outer neritic such as Textularia agglutinans Triloculina trigonula, Nionionella sp., globigerina glutinata and Alabamina sp.

3. The lithology is composed of mudstone, sandy mud, silts, clay and sands.

The inference of the water depth of the interval $14860-14,890 \mathrm{ft}$ as middle neritic-outer neritic is based on the following criteria:

1. The presence of indicator fauna such as Verneuilina scabra, Trochammina sp., Anomalina sp., Spirosigmoilina oligocaenia and Globigerinoides subquadratus.

2. Very high abundance and diversity of planktic and calcareous benthic foraminifera but few occurrence of arenaceous benthic foraminifera.

3. The main lithology of this water depth is constituted of shale and mudstones. Sands are deposited at some intervals occasionally in the study sequence.

\section{Paleoenvironment of deposition}

Inference of the paleodepositional environment of the studied wells was made based on the foraminifera distribution; paleobathymetry interpreted from the benthic foraminifera assemblages and lithologic description of the wells.

Based on lithofacies analysis of subfacies environment within Benin Formation (braided, fluvial point bar and crevasse splay) observed using various log motifs (blocky, fining upward and coarsening upward log shaped) present within these intervals from 7026.34 to $4409.2 \mathrm{ft}$ (well C), 7118.11 to $4040.71 \mathrm{ft}$ (well B) and 7235.17 to $6654.74 \mathrm{ft}$ (well A) (Fig. 4) and also based on very high percentage of sands $(75-86 \%)$ that were observed in this shallow sedimentary sequence, these intervals were dominated with fluvial activity. Hence, these can be suggestive of a continental environment.

Based on lithofacies analysis of subfacies environment (distributary tidal channel, intertidal and subtidal) observed using various $\log$ motifs (blocky and fining upward log shaped), marked decrease in sands percentage $(<50 \%)$ in the shallow marine sedimentary sequence present within this interval from $11,856.55$ to $7071.24 \mathrm{ft}$ (well C), 7118.11 to $9831.43 \mathrm{ft}$ (well B) and $11,980.24$ to $7235.17 \mathrm{ft}$ 
(well A) (Fig. 5), and also based on foraminifera distribution and water depth information (shallow inner neriticinner neritic) interpreted from benthic foraminifera (Fig. 2), these intervals can be suggestive of tidal flat environment.

Based on lithofacies analysis of subfacies environment (storm-dominated shelf and rework offshore bar) observed using various $\log$ motifs (serrated and symmetrical $\log$ shaped) with a sand percentage of about $10 \%$ present within this interval from $12,632.72$ to $11,856.55 \mathrm{ft}$ (well C) and $14,889.61$ to $13,485.74 \mathrm{ft}$ (well A) (Fig. 6) and also based on water depth information from benthic foraminifera (middle neritic to outer neritic), these intervals can be inferred as outer shelf environment.

\section{Seismic interpretation}

Seismic interpretation of Chiadu field revealed that the structural styles that characterize this field were mainly growth faults, synthetic and antithetic faults (crestal fault) and collapsed crested structures (Fig. 7). The presence of these faults in the study area is an indication that there is a possibility of hydrocarbon accumulation. Weber and Daukoru (1975) described faults as a conduit for hydrocarbon migration into the reservoir rocks. The growth fault occurred contemporaneously with sedimentation and resulted in the development of a relatively thick section on the downthrown side of the fault (Van Wagoner et al. 1990). The relationship of the well with the structural patterns is superimposed on the seismic data to identify the possible sequence stratigraphic surfaces on the seismic section (Fig. 7). By incorporating lithologic data and facies successions, seismic stratigraphy has given rise to more geological-oriented concept of sequence stratigraphy (Van Wagoner et al. 1988, 1990). The generated synthetic seismogram showed a near-perfect tie with over $90 \%$ confidence limit (Fig. 7).

Maximum flooding surface 2 and maximum flooding surface 3 correspond to positive amplitudes denoted by peak (blue color), while MFS 1 corresponds to negative amplitude denoted by trough (red color) (Fig. 7).

Three sequence stratigraphic surfaces: MFS 1, MFS 2 and MFS 3 were identified on the gamma-ray well $\log$. Horizons ( $\mathrm{H} 1, \mathrm{H} 2$ and $\mathrm{H} 3$ ) were tied to the sequence

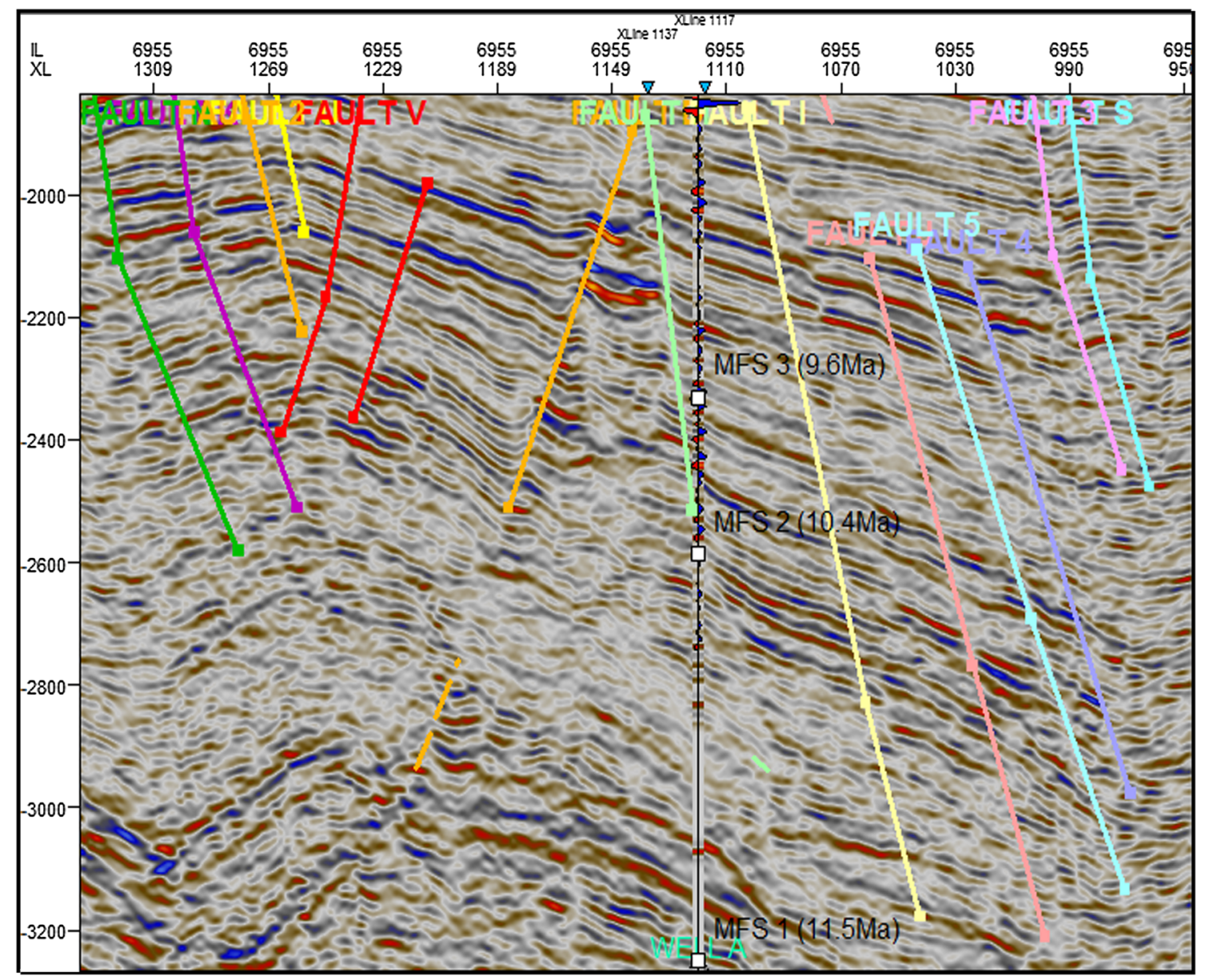

Fig. 7 Display of seismic-to-well tie using the generated synthetic seismogram and mapped structural framework

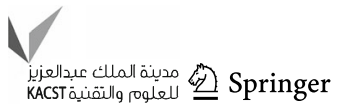




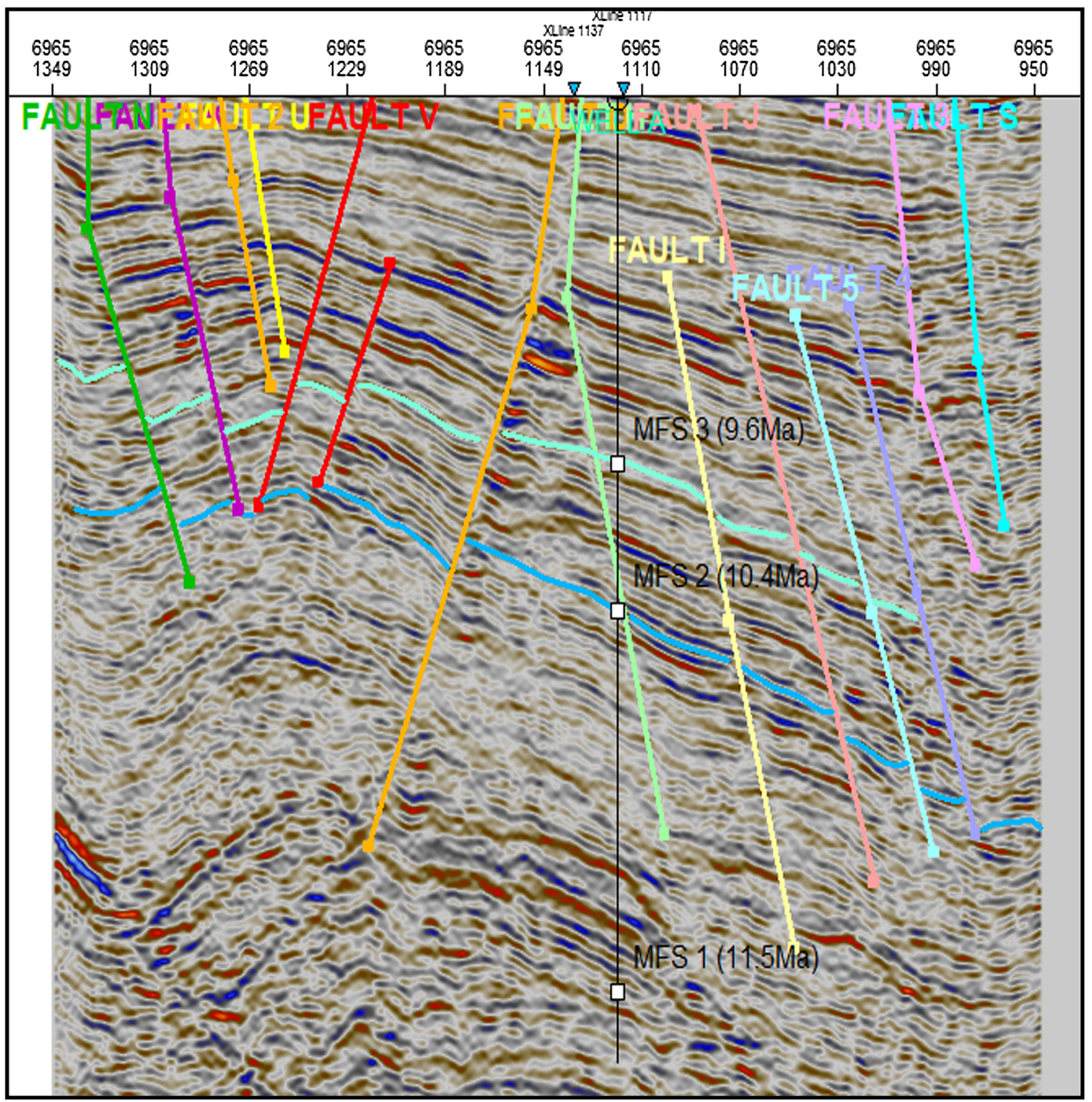

Fig. 8 Seismic cross section along Inline 6955 showing the horizon pick

stratigraphic surfaces. The horizons correlated were laterally continuous on the seismic record (Fig. 8).

\section{Sequence stratigraphic analysis}

\section{Genetic sequences, system tracts and key surfaces}

Sequence stratigraphy is a concept that involves the integration of biostratigraphy, paleodepth information and characteristic well-log signatures with seismic reflection profiles. The interpretation procedures of Galloway (1989) were employed in this study for the identification of maximum flooding surfaces (MFSs), sequence boundaries (SBs) and system tracts.
Sequence stratigraphic model of Chiadu field was based on well A. Three genetic sequences over the interval $14,856.34-10,380.09 \mathrm{ft}$ were identified.

Genetic sequence I $(14,856.34-14,083.43 \mathrm{ft})$

Genetic sequence (SEQ 1) is marked at the top by maximum flooding surface and commences at the base by a transgressive surface (Fig. 9). Galloway (1989), based on Frazier (1974), proposed that maximum flooding surfaces, rather than subaerial unconformities, be used as sequence boundaries. This unit was termed a genetic stratigraphic sequence. Gamma-ray $\log$ signature shows that this sequence starts from transgressive surface at an interval of 14,856.34 $\mathrm{ft}$ (Fig. 9). It is characterized by dominant shales 


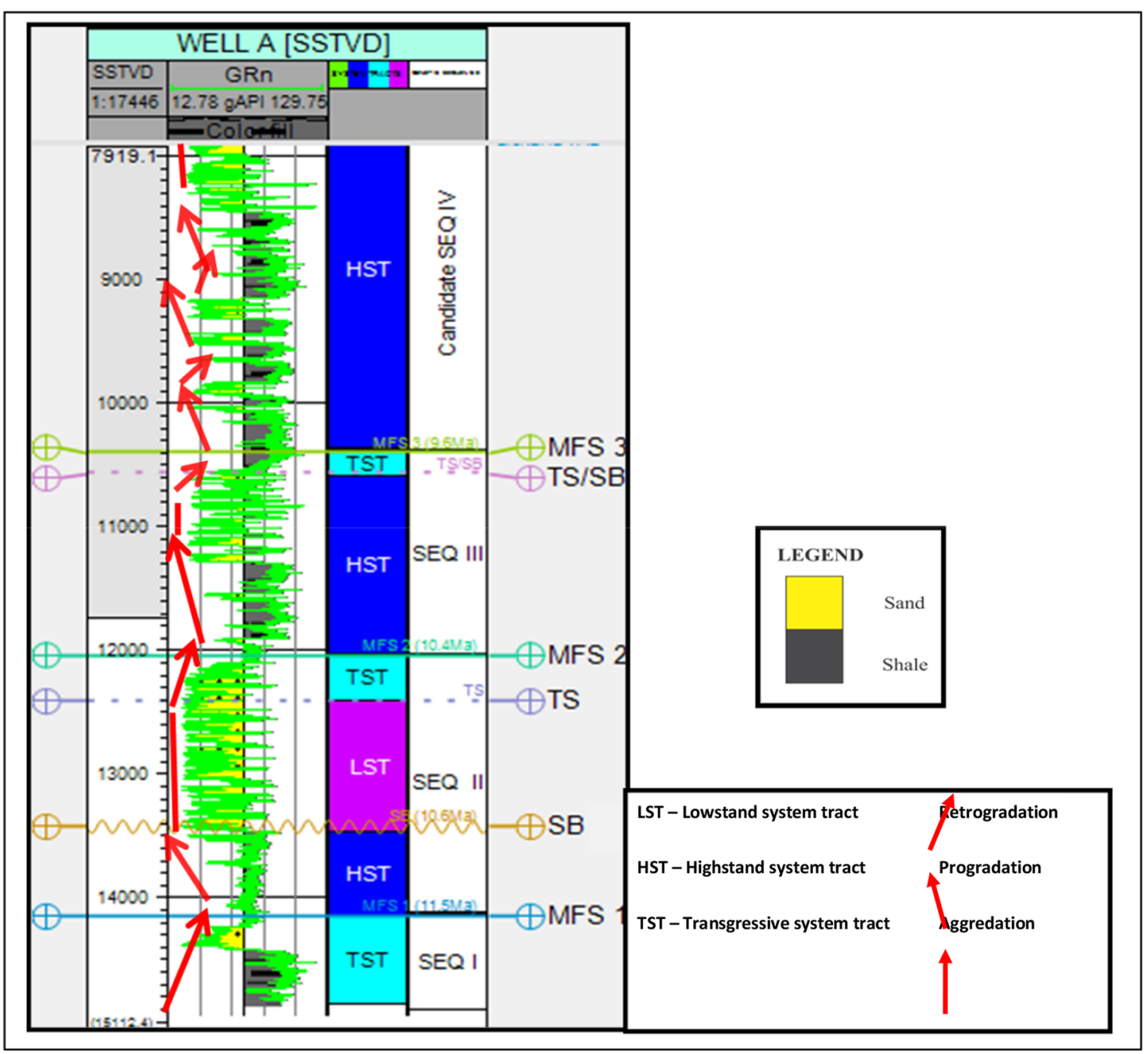

Fig. 9 Wireline log showing system tracts, parasequence sets and genetic sequences

with thin sandy intervals, and the shale facies shows high foraminifera abundance and diversity of planktic and calcareous benthic but barren of arenaceous benthic foraminifera. The entire sequence shows a retrogradational parasequence pattern (Fig. 9). Van Wagoner et al. $(1988,1990)$ defined parasequence as a relatively conformable succession of genetically related beds or bedsets bounded by marine-flooding surfaces.

This sandy interval shows a rework offshore bar; it consists of symmetrical (hour glass)-shaped sand unit, deposited during relative minor sea-level fall and rise. The transgressive system tract (TST) is characterized by thick shale section that shows retrogradational parasequence stacking pattern (Fig. 9), and the water depth has been inferred as middle neritic-outer neritic. The transgressive system tract (TST) was deposited during a relative sealevel rise. High GR and low resistivity values defined the maximum flooding surface (MFS 1) within this transgressive surface at $14,290.43 \mathrm{ft}$ (Fig. 9) together with high abundance and diversity of planktic and calcareous benthic foraminifera. The inferred water depth is inner neritic to middle neritic (Fig. 2). This maximum flooding surface (MFS 1) was correlated with well $\mathrm{C}$ at $12,360.54 \mathrm{ft}$ (Fig. 10).

\section{Genetic sequence II (14,083.43-11,957.49 ft)}

Genetic sequence (SEQ 11) commenced with highstand system tract (HST) from 14,083.43 to 13,028.69 ft (Fig. 9). This HST is characterized by aggrading parasequence stacking pattern developed during late relative sea-level rise and highstand of sea level. The HST is associated with shales/sandy mudstones and sandstone and terminates with blocky sand (aggrading) at 13,028.69 ft. The inferred water depth of the HST is shallow inner neritic (Fig. 2). The upper boundary of this HST marks the unconformity surface (sequence boundary), and this is known to be the shelfal LST (lowstand system tract) that was deposited 
Fig. 10 Correlation of genetic sequence of well $\mathrm{A}$ and well $\mathrm{C}$

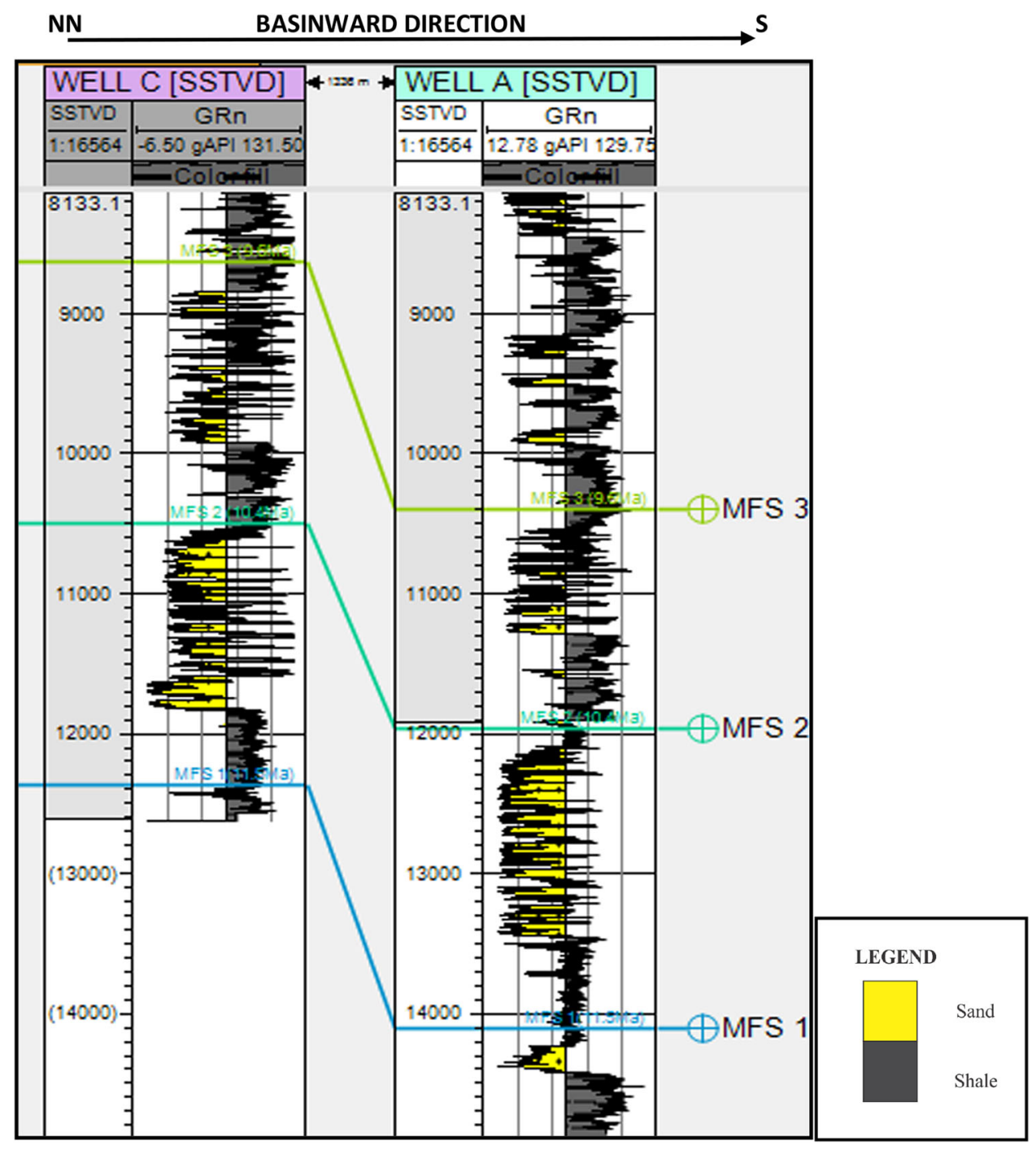

during relative sea-level rise. It was confined mainly to the proximal portion of the shelf often within non-marine strata (Posamentier and Vail 1988). Well-log character within this lowstand system tract exhibits cylinder log and fining upward log motif. It shows a retrogradational parasequence stacking pattern (Figs. 9, 10).

Transgressive system tract (TST) of this sequence commence from $12,265.07$ to $11,957.49 \mathrm{ft}$. This TST is characterized by upward fining (backstepping) parasequence stacking pattern deposited during a relative sealevel rise. High faunal and floral abundance and diversity characterized this TST. The maximum flooding surface (MFS 2) marks the end of this genetic sequence and has been recognized at $11,957.49 \mathrm{ft}$ (Fig. 9). The inferred water depth is inner neritic. MFS 2 was correlated with well $\mathrm{C}$ at 10,491.91 ft (Fig. 10).
Genetic sequence III (11,957.49-10,380.82 ft)

The third genetic sequence (SEQ III) commenced with the highstand system tract (HST) from 11,957.49 to 10,715.73 ft. The HST consists of dominant shale interval with thin coarsening upward sandy beds. It exhibits a progradational parasequence stacking pattern. The inferred paleodepth is shallow inner neritic. The sand interval from $11,285.30$ to $10,715.73 \mathrm{ft}$ exhibits aggradational parasequence stacking pattern (Fig. 9). The highstand system tract was deposited during relative sea-level rise and the highstand of seal level. The upper boundary of this highstand system tract represents the onset of the sequence boundary (SB 3) and transgressive surface that mark the next sea-level rise. The transgressive system tract (TST) of this sequence commenced at $10,715.73 \mathrm{ft}$. The transgressive system tract at interval of 10,715.73-10,396.27 ft shows fining upward transgressive sand bed. It exhibits a backstepping parasequence stacking pattern (Fig. 9). The 


\section{N \\ BASINWARD DIRECTION}
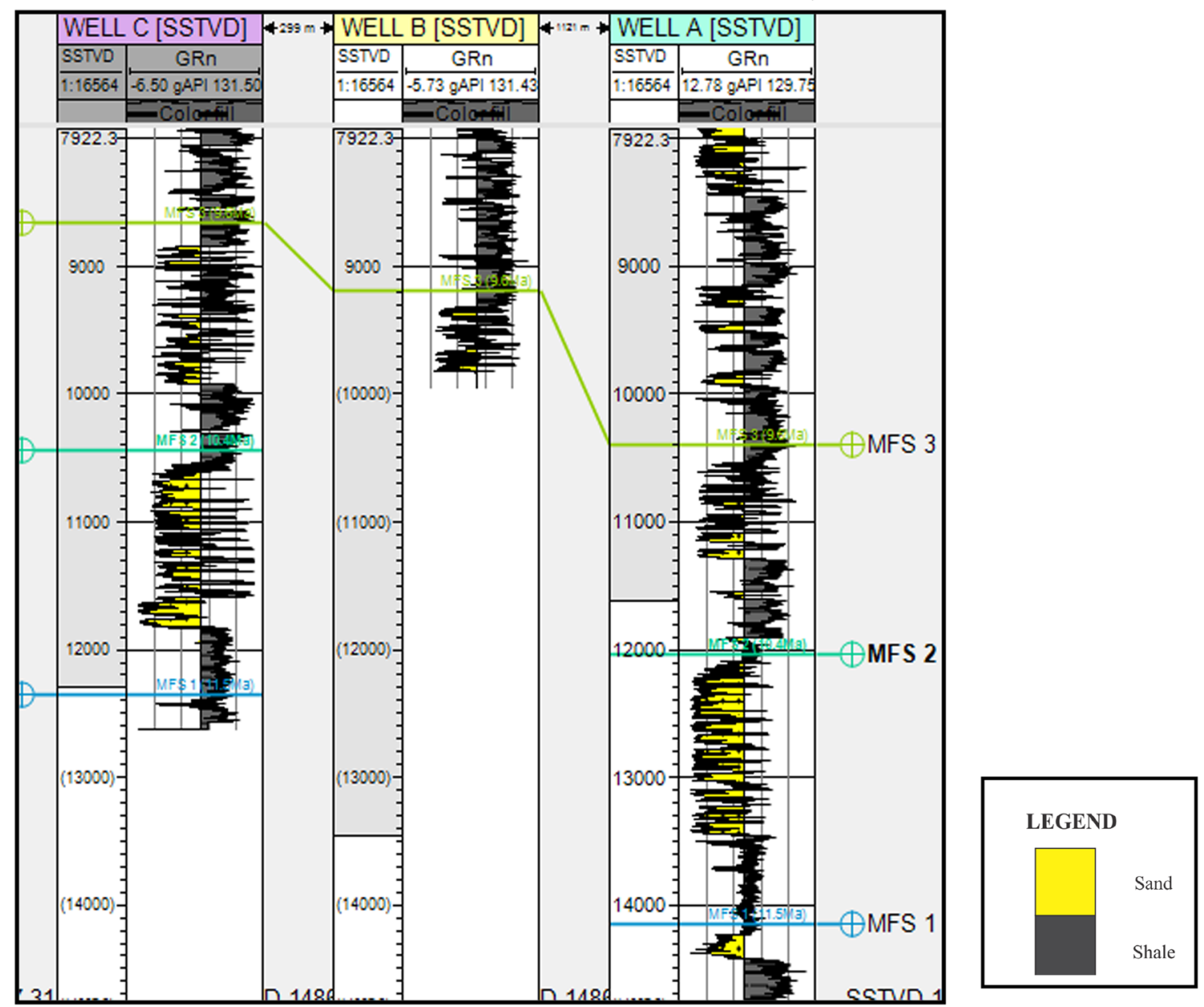

Fig. 11 Correlation of genetic sequence of well A, well B and well C

transgressive system tract was deposited during a relative rise in sea level. High faunal and floral abundance and diversity define the maximum flooding surface (MFS 3 ) at $10,395.27 \mathrm{ft}$. The inferred water depth is inner neritic to middle neritic. MFS 3 was correlated with well C and B at 8636.61 and $9188.37 \mathrm{ft}$ (Fig. 11).

\section{Exploration and development implication}

Sequence stratigraphy has allowed stratigraphers to emphatically expressed, most likely prudent predictions as to the composition of sedimentary packages in the geologic record. The mapping of key petroleum system enables us to select high-quality prospects, such as those associated with the shelfal lowstand system tract and highstand system tract. The shelfal reservoir sand tends to be best developed in shallow inner neritic water depths.

The tidal channel deposits of highstand system tracts are sealed by the overlain hemipelagic-pelagic shale of transgressive system tracts. The hemipelagic-pelagic shales of the transgressive system tracts of the study area are also excellent source rock. Thus, all the thick shales in the highstand system tracts in well A, well B and wells C of the Chiadu field have potential to be excellent source rock. The rapid facies changes between successive system tracts provide potential stratigraphic traps. Reservoir stratification and continuity vary greatly between system tracts, and this enhanced the development of stratigraphic traps in the study area.

\section{Conclusion}

The delineation and correlation of sequence stratigraphic surfaces enable us to build an approximate chronostratigraphic framework, which is essential for determining facies relationships. The success of this play encompasses delineation of a stratigraphic trap that depends on the reliability of the correlations and the subsequent facies analysis within the framework. 
The presence of water depths indicator fossils confirmed the water depths of coastal deltaic, shallow inner neritic, inner neritic, middle neritic and outer neritic that was based largely on the presence of environmentally restricted benthic foraminifera species. Paleoenvironmental interpretation is very useful for determining environments of deposition, which is a significant cost-effective input into petroleum reservoir management.

Based on the lithologic, foraminiferal and paleoenvironmental analysis, it is inferred that the intervals penetrated by the wells correspond to Agbada Formation. The alternation of sands and shales/mudstones within the sequence provides the combination of source, reservoir and seal rocks essential for hydrocarbon generation, accumulation and trapping. The maximum flooding surfaces derived from foraminifera peaks, abundance and diversities together with wireline log (GR and resistivity) signatures enabled the subdivision of the well into sequences and system tracts. HST, TST and LST are the recognized system tracts in the wells.

The shale units of the transgressive system tract of genetic sequences I and II in which most of the maximum flooding surfaces occur together with the highstand system tract of genetic II and III have been found to be the major source rocks and field-wide seal. The reservoir sands of the shelfal lowstand system tract of genetic sequence II and highstand system tract of genetic sequence III have been revealed to be major hydrocarbon reservoirs in the study. Up-dip lateral migration along faults (major and minor) has been identified as the probable hydrocarbon migration pathway. The hydrocarbon reservoirs of shelfal lowstand system tract and highstand system tract together with shale units of the transgressive system tract can form good stratigraphic traps for hydrocarbon.

High-resolution biostratigraphy, well-log analysis and seismic interpretation are the three fundamental make-up of sequence stratigraphy. All of these data have been analyzed and integrated in order to reduce uncertainty in correlating and mapping sequences and system tracts. The integration of the various datasets brings creative application to sequence stratigraphy that significantly increases the accuracy and reliability of geological interpretation. This method can be applied in frontier exploration as well as development of oil and gas fields.

The application of sequence stratigraphic framework acts as a basic guide to facies analysis, and one of the key essences of such analysis is to identify porous facies that may act as petroleum reservoirs.

\section{Recommendation}

The difficulties encountered in the interpretation and mapping of surfaces and structures at deeper horizons using the available datasets indicate that the seismic dataset used are characterized by poor imaging with increasing depth. Hence, reacquisition and/or processing should be done to improve seismic data quality for better imaging and interpretation/mapping, especially at deeper horizon. Deeper exploration wells should be drilled to provide data for analyzing and constraining deeper interpretations. In addition, studies should be carried out to better understand the stratigraphic/sedimentological controls on hydrocarbon prospecting in the area. Core data and sedimentological data should be provided and integrated in order to increase confidence in delineating the stratigraphic surfaces.

Acknowledgement We would like to appreciate Shell Petroleum Development Company of Nigeria for the release of the data sets for this research to be carried out and the Department of Geological Sciences of Nnamdi Azikiwe University for providing the workstation and needed geological software used in this study.

Open Access This article is distributed under the terms of the Creative Commons Attribution 4.0 International License (http:// creativecommons.org/licenses/by/4.0/), which permits unrestricted use, distribution, and reproduction in any medium, provided you give appropriate credit to the original author(s) and the source, provide a link to the Creative Commons license, and indicate if changes were made.

\section{References}

Adesida AA, Reijers TJA (1977) Sequence stratigraphic framework of the Niger Delta Basin. AAPG Annu Conf Abstr 99:13-59

Anderson JB, Wolfteich C, Wright R et al (1982) Determination of depositional environments of sand using vertical grain size progression. Gulf Coast Assoc Geol Soc Trans 32:565-577

Armentrout JM (1987) Integration of biostratigraphy and seismic stratigraphy: pliocene-pleistocene, Gulf of Mexico: Gulf Coast, sedimentology and paleontology. In: SEPM eleventh annual research, vol 1. Academic Press, pp 1-100

Avbovbo AA (1978) Tertiary lithostratigraphy of Niger Delta. AAPG Bull 62:295-300

Cant DJ (1984) Subsurface facies analysis. In: Walker RG (ed) Facies models. Geoscience Canada reprint series vol 1, 2nd edn, pp 297-310

Cant DJ (1992) Subsurface facies analysis. In: Walker RG, James NP (eds) Facies models, response to sea level change. Geological Association of Canada, pp 27-45

Ejedawe JE (1981) Patterns of incidence of oil reserves in Niger Delta Basin. AAPG Bull 65:1574-1585

Emery D, Myers KJ (1996) Sequence stratigraphy. Blackwell, Oxford, p p29

Evamy BD, Haremboure J, Kamerling P et al (1978) Hydrocarbon habitat of Tertiary Niger Delta. AAPG Bull 62:277-298

Frazier DE (1974) Depositional episodes: their relationship to the quaternary stratigraphic framework in the northwestern portion of the Gulf Basin. Geol Circ Univ Tex Austin Bur Econ Geol 1(1):p28

Galloway WE (1975) Process framework for describing the morphologic and stratigraphic evolution of deltaic deposition systems. In: Brousard ML (ed) Deltas, models for exploration. Houston Geological Society, Houston, pp 87-98 
Galloway GE (1989) Genetic stratigraphic sequences in basin analysis 1: architecture and genesis of flooding-surface bounded depositional units. AAPG Bull 73:125-142

Hentz TF, Hongliu Z, Kilic CO (2002) Sequence stratigraphy, depositional framework and resource potential of mature gas reservoirs, offshore Louisiana (abs.). In: AAPG annul convention program

Hospers J (1965) Gravity field and structure of the Niger Delta, Nigeria, West Africa. GSA Bull 76:407-422

Huang TC, Worrandt WW (1986) Plio-pleistocene sequence stratigraphy abundance peak correlation of seven wells in canyon, offshore Louisiana. Micro-Strat Inc. report, Houston, Texas

Israelsky MC (1949) Oscillation chart. AAPG Bull 33:92-98

Knox GJ, Omatsola EM (1989) Development of the Niger Delta in term of the escalator regression model and impact on hydrocarbon distribution. In: Proceeding KNGMG symposium "coastal lowlands". Kluwer Academic Publishers, Dordercht, pp 181-202

Ladipo KO (1992) Sequence stratigraphic analysis: an example of applications to prospect appraisal in the northern (western) Niger Delta, Nigeria. NAPE Bull 7:153-158

Lehner P, de Ruiter PAC (1977) Structural history of the Atlantic margin of Africa. AAPG Bull 61:961-981

Meckel LD (2003) Fourth-order deep water genetic stratigraphy, stratigraphic architecture and reservoir stacking patterns. In: AAPG international conference, Barcelona

Mitchum RM, Sangree JB, Vail PR et al (1993) Recognising sequences and systems tracts from well logs, seismic data and biostratigraphy: examples from Late Cenozoic of the Gulf of Mexico. AAPG Mem 35:163-197

Posamentier HW, Allen GP (1999) Siliciclastic sequence stratigraphy: concepts and applications. SEPM Concepts Sedimentol Paleontol 7:701-728

Posamentier HW, Vail PR (1988) Eustatic controls on clastic deposition II-sequence and systems tract models. In: Wilgus CK, Hastings BS, Kendall CGSC, Ross CA, Van Wagoner JC (eds) Sea level changes - an integrated approach. SEPM special publication, vol 42, pp 125-154

Rassi C (2002) Assessment of production predictability of fourthorder systems tracts in the miocene offshore Louisiana, Gulf Coast Association of Geological Societies, vol 52 (in press)

Rassi C, Hentz TF (2003) Production prediction and reservoir characterization of systems tracts of fourth-order sequence in the Miocene offshore Louisiana (abs). AAPG Annu Conv Offshore Program 10:164

Reijers TJA (2011) Stratigraphy and sedimentology of the Niger Delta. Geologos 17(3):133-162

Reijers TJA, Petters SW, Nwajide CS (1997) The Niger delta basin. In: Selly RC (ed) African basins. Sedimentary Basins of the world, vol 3. Elsevier, Amsterdam, pp 145-168
Rider MH (1990) Gamma ray log shape used as a facies indicator: Critical analysis of an oversimplified methodology, In: Hurst A, Lovell MA, Morton AC (eds) Geological application of wireline logs. Geological Society of London Special Publication Classics, pp 27-37

Selley RC (1978) Concepts and methods of subsurface facies analysis. AAPG continuing education course notes series, 9

Serra O, Abbott H (1982) The contribution of logging data to sedimentology and stratigraphy. SPE J 22(1):117-131

Slatt RM (2006) Stratigraphic reservoir characterization. Handbook of petroleum exploration and production. Elsevier, Amsterdam, pp 379-422

Sloss LL (1962) Stratigraphic models in exploration. AAPG Bull 46:1050-1057

Sloss LL (1963) Sequence in the cratonic interior of North American. GSA Bull 74:93-114

Stacher P (1995) Present understanding of the Niger Delta hydrocarbon habitat. In: Oti MN, Postma G (eds) Geology of deltas, pp 257-267

Vail PR, Wornardt WW (1991) An integrated approach to exploration and development in the 90's: well log-seismic sequence stratigraphic analysis. Gulf Coast Assoc Geol Soc Trans 41:430-650

Van Wagoner JC, Posamentier HW, Mitchum RM et al (1988) An overview of the fundamentals of sequence stratigraphy and key definitions. In: Wilgus CK, Hastings BS, Kendall CGSC, Posamentier HW, Ross CA, Van Wagoner JC (eds) SEPM special publication vol 42, pp 39-45

Van Wagoner JC, Mitchum RM Jr, Campion KM et al (1990) Siliciclastic sequence stratigraphy in well logs, core, and outcrops: concepts for high-resolution correlation of time and facies. Am Assoc Pet Geol Methods Explor Ser 7:p55

Weber KJ, Daukoru EM (1975) Petroleum geology of the Niger Delta. In: 9th World petroleum congress proceedings, Tokyo vol 2, pp 209-221

Weller JM (1960) Stratigraphic principles and practices. Harper and Brothers, New York, p 725

Wheeler HE (1958) Time stratigraphy. AAPG Bull 42:1047-1063

Wheeler HE (1959) Unconformity bounded units in stratigraphy. AAPG Bull 4(3):1975-1977

\section{Publisher's Note}

Springer Nature remains neutral with regard to jurisdictional claims in published maps and institutional affiliations. 